\section{Levamisole in Gastric Content after Unusual Intake of Heroin and Cocaine}

Nadia Fucci ${ }^{1 *}$ and Ronald Agius ${ }^{2}$

\begin{abstract}
Levamisole is an antibiotic medication used to treat colon cancer and is a synthetic imidazothiazole derivative also employed as an antihelminthic to treat worm infestations in both humans and animals. Even if it is not yet well known why levamisole is added to cocaine, the presence of this adulterant is very dangerous, in fact this compound suppresses the production of white blood cells, resulting in neutropenia, agranulocytosis and idiopathic pulmonary hypertension. With the increasing use of levamisole as an adulterant, a number of these complications have been reported among cocaine users. The authors refer about the detection of levamisole in gastric content taken from a 48- year old woman who was found deceased at home with no evidence of trauma or asphyxia. The cause of death was related to an overdose of cocaine and morphine, and the presence of levamisole in gastric contents was correlated to oral ingestion of a considerable amount of cocaine, a hypothesis suggested by the presence of white powder found on the walls of the stomach of the cadaver.
\end{abstract}

\section{Keywords}

Levamisole; Adulterant; Cocaine related deaths

\section{Introduction}

Levamisole is an antibiotic medication used to treat colon cancer and is a synthetic imidazothiazole derivative also employed as an antihelminthic to treat worm infestations in both humans and animals.Italian law restricts this drug to prescription use only. The presence of this compound was pointed out by Drug Enforcement Administration (DEA) laboratory in 2003-2004 and in the USA clandestine market of illicit cocaine in 2007 [1,2]. For the first time in Italy in 2007 [3,4] levamisole, phenacetin and hydroxyzine $[5,6]$ were detected as adulterants in illicit cocaine. Even if it is not yet well known why levamisole is added to cocaine, the presence of this adulterant is very dangerous. Recently it was reported that levamisole can lead to leukopenia and cutaneous manifestations [7]. Levamisole suppresses the production of white blood cells, resulting in neutropenia and agranulocytosis. With the increasing use of levamisole as an adulterant, a number of these complications have been reported among cocaine users [8,9]. Levamisole has also been linked to a risk of vasculitis [10] and cases of vasculitic skin necrosis

${ }^{*}$ Corresponding author: Nadia Fucci, Institute of Legal Medicine Catholic University of Rome, Largo Francesco Vito 1- Rome 00168, Italy, Tel: 003906 35507031; Fax: 003906 35507033; E-mail:- nadiafucci@rm.unicatt.it

Received: December 04, 2012 Accepted: March 29, 2013 Published: April 01, 2013 have been reported in users of cocaine adulterated with levamisole [11]. Agranulocytosis and neutropenians are easily diagnoses, but not so easily treated. Neutropenia or agranulocitosis in a drug user should now be considered strong evidence for a chronic ingestion of levamisole-contamined cocaine [9]. The presence of levamisole in biological fluids coming from human cadavers with cocainerelated deaths is recently reported in scientific literature [9]. Some authors recently referred about the conversion of levamisole to aminorex in human in vivo studies [12]; however, they underlined that the metabolic fate of levamisole in humans is unknown. Moreover a relation between anoretics, cocaine abuse, and idiopathic pulmonary hypertension is also underlined [9]. In this report the authors refer about the detection of levamisole in gastric content taken from a 48- year old woman, who was found deceased at home with no evidence of trauma or asphyxia. The woman suffered from depression for approximately five years and she was under treatment by a psychiatrist. The cause of death was related to an overdose of cocaine and morphine, the presence of levamisole in gastric contents was correlated to oral ingestion of a considerable amount of cocaine, a hypothesis suggested by the presence of white powder found on the walls of the stomach of the cadaver.

\section{Materials and Methods}

For the detection of morphine, cocaine, benzoylecgonine in biological sample a liquid/liquid extraction was performed on 1 milliliter of each biological sample (blood-urine and gastric content) spiked with 25 milliliter of a mixture of $10 \mathrm{ng} / \mathrm{ml}$ deuterated internal standards obtained by LGC Standards (only for morphine, cocaine and benzoylecgonine). An external standard purchased from LGC standards-Milano-Italy, was employed to quantify the levamisole since no deuterated internal standard was available. Qualitative and quantitative determination were performed according to analytical procedures previously validated [13]. A liquid/liquid extraction with $3 \mathrm{ml}$ of chloroform/isopropanol (9:1) at alkaline $\mathrm{pH}$ was performed. The extracts were evaporated to dryness and reconstituted in 20 microliter. Subsequently the extracts were derivatized using 50 microliter PFPA and 30 microliterpentafluoropropanol. One microliter of each sample was injected in the GC/MS. GC/MS analysis were performed on a model 5890 gas chromatography fitted with a split-splitless injector $\left(270^{\circ} \mathrm{C}\right)$ equipped with a HP 1 capillary column (12 $\mathrm{mt} 0.2 \mathrm{~mm}$ i.d.) $0.3 \mathrm{~mm}$ film thickness methylsilicone. A linear programme from 70 to $28^{\circ} \mathrm{C}$ at $10^{\circ} \mathrm{C} /$ minutes increments with a 5 minutes final isothermwas chosen. Heliumwas employed as the carrier gas at a columnhead pressure of 10 psi. The capillary column was connected to amass analyzer (HP 5971A) operated by electron impact $(70 \mathrm{eV})$ in selected ion monitoring .The acquisition in SIM mode was performed by choosing three ions for each compound (cocaine: $\mathrm{m} / \mathrm{z}$ 182,303,198; cocaine - $\mathrm{d} 3: \mathrm{m} / \mathrm{z}$ 185,306.201; benzoylecgonine $: \mathrm{m} / \mathrm{z}$ 300,421,316; benzoylecgonine-d3: m/z 303,424,319; morphine: $\mathrm{m} / \mathrm{z}$ 414,577,558; morphine -d3: m/z 417,580,561; monoacetylmorphine : m/z 414,473,361; monoacetylmorphine-d3: 417,476,364; levamisole: $\mathrm{m} / \mathrm{z} 73,148,204)$ 


\section{Results and Discussion}

The toxicological analysis performed on the corpse showed the presence of cocaine and morphine in the biological samples. Moreover the presence of levamisole was revealed in illicit cocaine and in gastric content, the presence of this drug in blood and urine sample was excluded. Moreover the presence of aminorex (metabolite of levamisole) was also excluded. In Table 1 are reported the concentration revealed for all the biological samples examined. The concentrations of cocaine and heroin and its metabolitesexceed the lethal values referred to the literature [14]. Hence, the woman's dead was attributed to an overdose due to the cocaine and heroin for oral ingestion and intravenous injection.Traces of minor alkaloids of Eritroxylon coca and adulterants were also found in illicit cocaine. The syringe eluate showed the presence of traces of morphine, cocaine, cis- and trans-cynnamoilcocaine, tropococaine and levamisole. No trace of drugs was revealed in the eluates obtained for nasal swabs.

Table 1: Concentration of cocaine, benzoylecgonine, morphine, monoacetylmorphine and levamisole detected in the biological samples examined.

\begin{tabular}{|l|c|c|c|c|c|}
\hline & $\begin{array}{c}\text { Benzoy- } \\
\text { lecgonine }\end{array}$ & Cocaine & $\begin{array}{c}\text { Mor- } \\
\text { phine }\end{array}$ & $\begin{array}{c}\text { Monoacetyl- } \\
\text { morphine }\end{array}$ & Levamisole \\
\hline Blood & $\mathrm{ng} / \mathrm{ml}$ & $\mathrm{ng} / \mathrm{ml}$ & $\mathrm{ng} / \mathrm{ml}$ & $\mathrm{ng} / \mathrm{ml}$ & $\mathrm{ng} / \mathrm{ml}$ \\
\hline Urine & 200 & 300 & 100 & 250 & negative \\
\hline Gastric Content & 2800 & 2000 & 500 & negative & negative \\
\hline
\end{tabular}

$\mathrm{ng} / \mathrm{ml}=$ nanograms/milliliter

\section{A)}

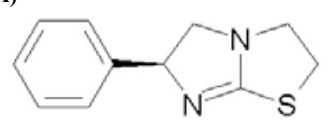

B)

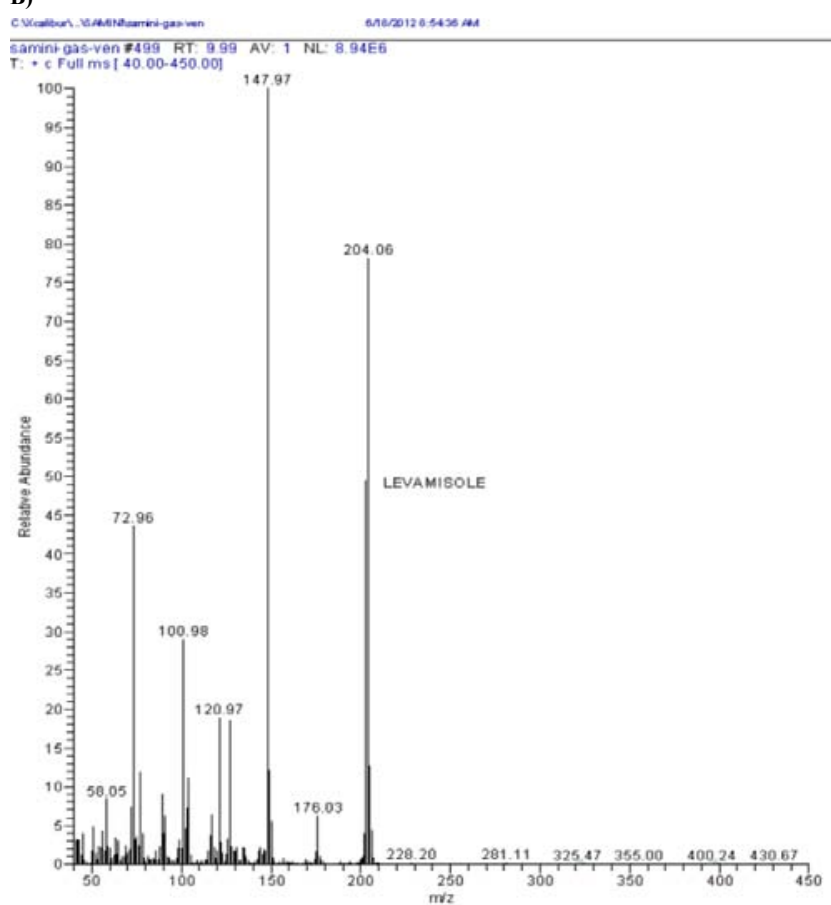

Figure 1: A) Chemical formula of levamisole. B) Mass spectrum of levamisolefoundin gastric content.
The mass spectrum obtained for levamisole found in gastric content is shown in Figure 1. Moreover in the gastric content the presence of levamisole was revealed trace amount of opiates and cocaine were also detected in the syringe; on the contrary in the residues contained in the enclosures, the presence of cocaine, minor congeners and levamisole were detected.

The case discussed is very particular with respect to the modality of drugs ingested, namely cocaine and opiates, probably due to psychiatric disorders of the deceased woman. Although there is a remarkable fact particularly linked to the discovery of levamisole in the stomach probably due to ingesting a large quantity of drugs.

Precisely because of the wide spread use of levamisole in illicit cocaine we advise the additional screening for levamisole in biological fluids of "overdose"-related deaths.

Because levamisole is very common in samples of cocaine, as already observed elsewhere in Italy, in Europe and USA, and as the true percentage is not known, we believe this information could be useful. The presence of levamisole in cocaine suggested the increase of some symptoms as agranulocytosis, necrotizing vasculitis and idiopathic pulmonary hypertension;neither condition is very common and their diagnosis, particularly in a young person, should initiate a search for levamisole-contaminated cocaine [15]. Sixty-nine percent of cocaine in the United States is adulterated with levamisole, in 2008, the first cases of levamisole-induced agranulocytosis and vasculopathy associated with adulterated cocaine were reported in the southwestern United States. Since then, reports of levamisoleassociated toxicity have become increasingly common [16]. The widespread abuse of cocaine suggests that the hazard is due not only for the occurrence of levamisole-induced agranulocytosis but also for a potential epidemic of pulmonary hypertension in chronic abusers.

We believe that in Italy the alert needs to be high in relation to the constant increase in cocaine use by a large percentage of the population.Moreover we also hope to further studies in relation to the hazard to human health associated with the levamisole.

\section{References}

1. Anonymous (2004) Diltiazem, hydroxyzine, and methylephedrine identified in separate shipments of cocaine. Microgram Bull 8:137.

2. Valentino AM, Fuentecilla K (2005) Levamisole: an atypical profile. Microgram J 3: 134-6.

3. Fucci N (2007) Unusual adulterants in cocaine seized on Italian clandestine market. Forensic Sci Int. 172: e1.

4. Anonymous (2009) Diltiazem, hydroxyzine and methyefedrine identified in separate specimens. National Early Warning System of the Council of Ministers of Italy.

5. Fucci N (2004) Phenacetin and cocaine in a body packer. Forensic Sci Int 141: $59-61$.

6. Odeneal II NG, Casale JF, Wojno HL (2004) Microgram J 2: 1-2.

7. Morris GW Jr, Mason BC, Harris Sprunger R, Hake Harris H, White LA, et al. (2012) Levamisole-adulterated cocaine: a case series. J Am Board Fam Med 25: 531-535.

8. Buchanan JA, Lavonas EJ (2012) Agranulocytosis and other consequences due to use of illicit cocaine contaminated with levamisole.Curr Opin Hematol 19: $27-31$.

9. Karch SB, Mari F, Bartolini V, Bertol E ( 2012) Aminorex poisoning in cocaine abusers. Int J of Cardiol 158: 344-346. 
10. Menni S, Pistritto G, Gianotti R, Ghio L, Edefonti A (1997) Ear lobe bilateral necrosis by levamisole-induced occlusive vasculitis in a pediatric patient. Pediatr Dermatol 14: 477-479.

11. Bradford M, Rosenberg B, Moreno J, Dumyati G (2010) Bilateral necrosis of earlobes and cheeks: another complication of cocaine contaminated with levamisole. Ann Intern Med 152: 758-759.

12. Bertol E, Mari F, Milia MG, Politi L, Furlanetto S, et al. (2011) Determination of aminorex in human urine samples by GC-MS after use of levamisole. $J$ Pharm Biomed Anal 55: 1186-1189.

13. Fucci N, De Giovanni N (2007) Methadone in hair and sweat from patients in long-term maintenance therapy. Ther Drug Monit 29: 452-454.

14. Winek CL, Wahba WW, Winek CL Jr, Balzer TW (2001) Drug and chemica blood-level data 2001. Forensic Sci Int 122: 107-123.

15. Czuchlewski DR, Brackney M, Ewers C, Manna J ,Fekrazad MH, et al. (2010) Clinicopathologic features of agranulocytosis in the setting of levamisoletainted cocaine. Am J Clin Pathol 133: 466-472.

16. Metwally O, Hamidi M, Townsend L, Abualula H, Zaitoun A, et al. (2013) The cocaine trail: levamisole-induced leukocytoclastic vasculitis in a cocaine user. Subst Abus 34: 75-77.

\section{Author Affiliations}

1 Institute of Legal Medicine Catholic University of Rome, Largo Francesco Vito 1- Rome 00168, Italy

'LaborKrone, Siemensstr 40, D-32105, Bad Salzuflen, Germany

Submit your next manuscript and get advantages of SciTechnol submissions

* 50 Journals

* 21 Day rapid review process

* 1000 Editorial team

2 Million readers

- More than 5000 facebogk

- Publication immediately after acceptance

* Quality and quick editorial, review processing

Submit your next manuscript at • www.scitechnol.com/submission 